\title{
The Nigerian Stock Exchange and Economic Growth (1980 - 2011) an Econometric Approach
}

\author{
Michael Baghebo(Ph.D), Adjejevwe Oghenetega John, \\ Department of Economics, Niger Delta University, Wilberforce Island, Bayelsa State Nigeria. \\ Department of EconomicsNiger Delta University, Wilberforce Island,Bayelsa State, Nigeria
}

\begin{abstract}
The study empirically examine the impact of the Nigerian Stock Exchange on economic growth from 1980-2011. The period was considered appropriate for the study in view of the challenges of building a strong financial base for the economy for long term investment that stimulate economic growth and development of Nigeria. Over the years, Nigeria capital market has developed in a more reliable market in terms of accessibility of funds. Also, the capital market form the basis in which assets and other near money such as shares and bonds can be easily converted into cash. For the purpose of this work, data were sourced from the Central Bank Statistical Bulletin; on various issues (1980-2011).The study revealed that Nigerian Stock Market has experienced a tremendous expansion when compared with what it used to be in recent years. This expansion cut across the volume of traded shares and other securities which runs into Millions of Naira. The result further revealed that with the provision of a place for the exchange of securities, the Nigerian Stock Exchange helped in the mobilization and allocation of capital resources among numerous competing alternative used in the stock exchange. The exchange provides sufficient liquidity for investors or group of investors who wish to invest their money. Also, Nigerian Stock Exchange encourages more sufficient allocation of wealth. This assertion was made possible as a result of the authentication of the variables such as GDP, GCF, ASI MCAP, EXCHR used in carrying out the work through the use of econometrics tools of ordinary least square (OLS) analyses and other econometrics test such as stationarity test, cointegration test, over-parameterized error correction test, parsimonious error correction test. Therefore, the government through her regulatory agencies be prudent in the management of exchange rate to ensure that the Nigerian Stock Exchange will be more efficient. The government should try to; establish a unit trust, give incentives to demand for listed securities, privatization of government owned business, development of analyst services and processing of new security.
\end{abstract}

Keywords: Stock Exchange, Econometric, Co integration, Error correction Economic Growth, Nigeria.

\section{Introduction}

The Nigerian Economy has over the years and various administrations have been subjected to series of social, political and economic policies and reforms. In the 1970 era, the economy was basically agrarian and solution to foods scarcity was largely achieved with the various regional governments. The need to encourage private capital in development was realised long enough with the establishment of the Nigerian Stock Exchange (then called the Lagos Stock Exchange) in 1961 to develop the capital market.

It is expedient to know that the level of investment growth which in turn has positive effect on a country's GDP is determined by the effective operation of the stock market. Also, the insurance Act of 1976 modifies and expands the earlier insurance practice in Nigeria governing insurance company to invest certain minimum proportion of their funds in prescribed securities which are listed on the stock exchange. The above legislation, helped in forcing some individuals or institution to buy or invest their capital in some of the exchange securities which under normal condition they would never have chosen. Other important measures carried out by the government to improve stock market operations was the Nigeria enterprise promotion decree in 1972/1977. The Nigeria enterprise promotion Act of 1972 and 1977 increases the number of listed equities from 14 in 1971 to over 90 by the end of 1980.

The transition from Lagos Stock Exchange to Nigerian Stock Exchange by the middle of 1970 was because of dissatisfaction that people expressed about the financial system of the capital market among other reasons. Therefore, the area of concern of this work will be to see the contribution of the stock market in ensuring availability of capital to boast the economic growth of the Nation (GDP).

This work is being carried out to provide solution to the problems often faced by the stock market in ensuring effectiveness in achieving their objective and towards contributing to the economic growth. It is obvious that corporate firms face a lot of challenge in obtaining required funds to expand their business as a result of unavailable or insufficient funds in the stock market. Therefore, the need to improve the functioning of the Nigerian Stock Exchange in ensuring availability of fund for investment purpose becomes a formidable task in this study. 
The lack of public awareness of the functions and operations of the establishment (stock market) is a major problem because a large number of the population does not know how the stock market operates and as such, tend not to know most of the functions of the exchange which this work will try to examine to the better understanding of an average Nigerian.

In addition, most Nigerians do not invest in securities but rather prefer to keep their money in bank or other financial institutions due to the unstable nature of the market in terms of prices of securities, share etc. consequently, people prefer to invest or keep their money in bank where they are sure of getting interest and real value of the money will not depreciate as often witness in the stock market when prices of shares or securities fails to achieve their set goals and objectives which will be highlighted in the study.

Also, the knowledge gap that this work tends to fill is the need to remove imperfection in the stock market in the form of information symmetry and transaction cost which is needed to facilitate the use of the market by private sector or corporate bodies to raise funds. The rest of the paper is organised as follows. Section two contains literature review, theoretical framework is in section three, methodology and data sources is taken up in section four, section five treats model estimation, data analysis and interpretation of results is in section six, recommendations are treated in section seven, while section eight concludes the study.

\section{Lterature Review}

Robert Barro (1990) reported that in the case of U.S., stock market variables and stock returns, can largely explain the subsequent aggregate investments, he proved this by regressing the average growth rate in per capita output on the market capitalization and he discovered that the stock market accounts for a larger part of the aggregate investment in U.S. Harris, Richard(1997) analyzed data for forty-nine countries over the period 1980-91 for the growth in GDP per unit of effective labor, investment as a percent of GDP, the growth of total employed labor and the total value of shares traded on the stock market as a percent of GDP. The study reported that the level of stock market activity has little explanatory power in the sample of developing countries and weak explanatory power for the sample of developed countries.

Seyyed, Oskooe (2012), studied emerging stock market efficiency using nonlinearity and episodic dependence evidence from Iran Stock market covering the period from 1997-2006. He conducted causality test within the vector error correction model framework, he also used Johansen co-integration analysis to investigate whether the variables are co-integrated of the same order taking into account the maximum eigen values and trace statistics test. He applied the granger causality test in order to find the direction of causality between the examined variables of the estimated model. He concluded that the level of real economic activity is the main factor in the movement of stock prices in the long run and stock market plays a role as a leading economic indicator of future economic growth in Iran, in the short run.

Levine and Zervos (1996), applied regression analysis to the data compiled from 41 countries for the years 1976 through 1993 to see the relationship between Stock market development and long run growth. One of the financial deepening indicators used in the analysis was the level of development of stock exchange measured by a composite index, liquidity and diversification indicators. Economic growth indicator selected, on the other hand, was the real growth rate in per capita GDP. Levine and Zervos reported a very strong positive correlation between stock market development and economic growth. The most interesting aspect of this study was the decrease in the statistical significance of other financial deepening variables after stock market development index was included in regression equation. The study concluded with the proof that stock market development is more influential than other financial deepening indicators on the growth of the economy.

Mohtadi and Agarwal, (2008) examined the relationship between stock market development and economic growth for 21 emerging markets, Nigeria inclusive, from 1977 to 1997, using a dynamic panel method. The variables used were Market capitalization ratio, total value of shares traded ratio, turnover ratio, GDP, Foreign direct investment, Investment, Secondary school enrollment. The model was estimated in several different ways such as OLS, fixed effects, random effects, one way, and two -way models. Following the tradition, Hausman test was used to test for the appropriateness of the fixed versus random effect and F test was used to choose between the one-way or two - way models. Their result suggested a positive relationship between several indicators of the stock market performance and economic growth both directly, as well as indirectly by boosting private investment behavior. Thus they lend support both to financial intermediation literature as well as to traditional growth literature.

The study by Arestis, et al( 2001) found that in countries like Germany, stock market volatility has a significant and negative impact on growth. The study used a vector autoregressive model to study the relationship between stock market development measures and economic growth for developed economies, controlling for the banking sector development. The study finds that the stock market and economic growth both may be able to promote growth, with the impact of the banking system being stronger. With well-functional financial sector or banking sector, stock markets can give a big boost to economic development (Rousseau and Wachtel, 2000) 
Nourzad (2002) analyzed the effect of financial development on productive efficiency using eight measures of financial development for countries at different stages of economic development. The study analyzed three sets of panels of data: annual data for twenty-nine countries from 1966-90, annual data for eighteen countries from 1970-90 and five year average data for twenty-eight countries from 1970-90. The author finds that productive efficiency is greater in countries that have more developed financial sectors i.e. the stock market.

\section{Theoretical Framework}

In an attempt to evaluate the role and performance and efficiency of the Nigeria stock exchange toward enhancing economic growth and development, it is important to look at the market efficiency theory and the efficiency market hypothesis which are the theories this work will focus in bringing out the contributions of the stock exchange to the growth of Nigerian economy.

The efficiency of the capital market where Nigeria stock exchange falls can be classified into the following:

i. Resources allocation efficiency

ii. Operational efficiency

iii. Information processing efficiency

i. Operational efficiency: this concept relates to the cost of financing operation. The lower the transaction cost, the higher the operational efficiency.

ii. Information processing efficiency: this reflects the extent to which information on the future of a security is reflected in its current share price. The information processing machinery where efficiency will ensure that future prospective information that would add value to the company is immediately reflected on the share price immediately it is known. This means that the investment market becomes fair" every investor informed and has equal chance in the market pay a 'fair' price and earn "fair" returns on investment.

iii. Resource allocation efficiency: a market will have allocation efficiency if resources will be directed towards most productive enterprises. In this situation, the most efficient enterprise will find it easier to raise funds for economic prosperity. The poor performance of a company will be quickly reported to the market and subsequently reflected and a fall in the share price due to secondary market trading. Most managers will equally be concerned with depressed share price as there is likely going to be a takeover, hence, attempt will be made to improve the efficiency of their operations.

Therefore, for a stock market to perform the function for which it is established and to justify its raison deter, it must be efficient in its operation character. Thus, efficient information must be freely available for rational profit maximization investor, stock prices must be so fairly valued that the average investors will receive an average return because the market will be an efficient price of earning potential and risk.

\subsubsection{Market Efficiency Theory}

According to Fama (1976) an efficiency market is a market that is efficient in processing information. In an efficient market, prices reflect available information. Market efficiency when viewed from the perspective of efficient market hypothesis may be defined at three levels:

i. The weak form

ii. The semi-strong form

iii. The strong form.

The essence of the market efficiency theory is to relate the theory to one of the problems of disseminating vital information as regards the activities and function of the stock exchange and to see the possibility of attaining the expected growth level in the economy of the market (stock exchange) is efficient in its functions.

\section{The Weak Form}

The weak form of the efficient market hypothesis assures that current security prices affect only historical information. It does not anticipate the future. Any point in time, the value of a security reflects volume and time changes in the past. Thereby, analysis in the past will not beat the nearest because, the information had already been reflected in the share price

\section{semi-strong form.}

This state that, current market price reflect all publicly available information. The semi-strong form encompasses the weak form because; all the market information considered by the weak form hypothesis such as security price, rate of returns and trading volume is public. Public information also includes all non-market information such as earning and dividend announcements, news about the economy and political news. A security's price in this form of market will reflect this information instantly and only its "fair" return can be earned by public in a market trading. 


\section{The Strong Form}

This state that current prices reflect not only the historical and current public information but also insider (private) information about the company and hence, future information about the company.

\subsubsection{The Efficiency Market Hypothesis (EMH)}

The efficiency market hypothesis argues that "today's price which reflects all current information is the best estimate for tomorrow present value price". The determination of that price is the function of an unencumbered freely operational efficiency stock market. The desirability at this type of market in socioeconomic terms is to ensure that savings are channelled into the most profitable investment and capital thus, allotted optimally. The Nigerian stock exchange is a far cry from this characterisation and is under developed, not only is the market lacking in-depth, there is little and new public issues by private enterprises, beyond those necessitated by the enterprise promotion Act of 1977 are few and far between and substantially insignificant, the number of pluses exceeding minus the extent of demand over supply of securities.

\section{Implications of Efficiency Market Hypothesis.}

Signs of strong or semi-strong efficiency cannot be beaten by the investor in the market that shows a "sport shares" at a bargain price that increases in value. This is because, the market will already have anticipated development in the future and reflect those share prices. What the investors needs to do is to concentrate on building good spread of shares (port-folio) in order to achieve a satisfactory balance between risk and returns.

If the strong form of the efficiency market is current, a company real financial position will be reflected in its share price. The real financial position includes both its current position and its expected future profitability. Making profit from insider dealing would not be possible since all information is available to the market.

Similarly, if the semi-strong is true, it will be possible for investors to make a speculative bargain on the bases of profitability available information. Indeed, not even fund manager can consistently beat the market. This does not preclude fair profit being made overtime for the risk taken by investing.

Thus, the fund managers in semi-strong case should manage both the underlying projects and information publicly available concerning the company and its project such information may "signal" import and facts that might be used to predict equity cash flows.

\section{Methodology And Data Sources}

We adopt three stages methodology. The stationary status of the time series data was investigated using Philip Perron unit root test, this is followed by Johansen co integration test. We also test for the short run dynamic adjustments required for establishing long run equilibrium relation among the variables using the over parameterized and parsimonious error correction method

Secondary data is used in collation of data for this research. The sources of data are the publications of Central Bank of Nigeria (CBN) such as CBN statistical bulletin, CBN statements of Accounts and annual reports, articles and journals as well as Federal Office Statistics (now National Bureau of Statistics) Publications of relevant years. The relevant variables sourced include: average stock index, market capitalization, exchange rate, gross capital formation, gross domestic product.

\section{Model Estimation}

It has been tested that all capital market have some element of imperfections, the degree and severity of information and agency problems varies among developed and developing capital markets, but institutional factors have helped to minimize imperfection in the capital markets of developed economies. It is still highly pronounced in developing economies like Nigeria. therefore, this work gives an over view of the significant role of the variables included in the model i.e all-share index, gross capital formation, exchange rate and market capitalization.

The model estimating the impact or contribution of the stock market variables such as; all share index, gross capital formation, market capitalization exchange rate is stated using the market efficiency theory.

The functional form of the model is stated as;

$\mathrm{GDP}=\mathrm{f}(\mathrm{ASI}, \mathrm{GCF}, \mathrm{EXCHR}, \mathrm{MCAP})$

The econometric form of the model is stated thus:

$\begin{array}{lll}\text { RGDP }= & \mathrm{a}_{0}+\mathrm{a}_{1} \mathrm{asi}+\mathrm{a}_{2} \mathrm{gcf}+\mathrm{a}_{3 \text { rexchr }}+\mathrm{a}_{4} \mathrm{mcap}+\mathrm{U}_{\mathrm{i}} \\ \text { Where } & & \\ \text { RGDP } & = & \text { Real Gross Domestic Product } \\ \text { Asi } & = & \text { Average stock index } \\ \text { Gcf } & = & \text { Gross capital formation } \\ \text { RExchr } & = & \text { Real Exchange rate } \\ \text { Mcap } & = & \text { Market capitalization }\end{array}$


$\mathrm{a}_{0}, \mathrm{a}_{1}, \mathrm{a}_{2}, \mathrm{a}_{3}$ and $\mathrm{a} 4=$ Parameters

$\mathrm{U}_{\mathrm{i}} \quad=\quad$ Error term

It is expected that $\mathrm{a}_{0}>0, \mathrm{a}_{1}>0, \mathrm{a}_{2}>0, \mathrm{a}_{3}>0$ and $\mathrm{a} 4>0$

6. DATA ANALYSIS AND INTERPRETATION OF RESULTS.

Results of Unit Root Test on the Contribution of Stock Market Variables (ASI, GCF, MCAP, EXCHR,) On GDP.

Table 1.Philip Perron's Unit Root Test Results

\begin{tabular}{|l|l|l|l|l|l|}
\hline VARIABLES & LEVELS & $1^{\text {ST }}$ DIFF & $2^{\text {ND }}$ DIFF & LAG & DECISION \\
\hline GDP & 4.867461 & 0.486335 & -4.304052 & 2 & $1(0)$ \\
\hline ASI & 1.432402 & -4.291235 & -7.412365 & 2 & $1(1)$ \\
\hline MCAP & -1.046009 & -4.065106 & -6.845082 & 2 & $1(1)$ \\
\hline GCF & 4.527373 & -3.121207 & -8.395840 & 2 & $1(0)$ \\
\hline EXCHR & -0.460208 & -3.916120 & -6.979846 & 2 & $1(1)$ \\
\hline ECM(-1) & -4.173599 & -6.688976 & -10.46550 & 2 & $1(0)$ \\
\hline CRITICAL & & & & & \\
VALUES & -3.8572 & & & & \\
$1 \%$ & -3.0400 & & & & \\
$5 \%$ & -2.6608 & & & & \\
$10 \%$ & & & & & \\
& & & & & \\
\end{tabular}

To test for the stationary or non-stationary status of the variable (GDP, MCAP, ASI, EXCHR, GCF) in the model, we use Philip-Perron's unit root test with linear deterministic trend. The result revealed that GDP and GCF were stationary at levels while ASI, MCAP and EXCHR attained stationarity after first difference. The critical values which form the bases of our decision making are 1\%,5\% and $10 \%$ levels respectively.

The ECM (-1) was highly significant and was integrated of the order zero. The null hypothesis of non stationarity of the variables is therefore rejected at the respective critical levels because; the variables MCAP, EXCHR and ASI attained stationarity after first difference while GDP and GCF were stationary at levels.

After ascertaining the stationarity of the variables and to avoid spurious and nonsensical regression results, we proceed to establish whether long-run equilibrium relationship exist among the variables in our model using Johansen cointegration rank test of Marx Eigen value. If the variables are cointegrated, they are referred to as policy variables. The statistical equivalence of long run equilibrium relationship among variables in a model is cointegration. According to Engel Granger, if two or more variables are cointegrated, the relationship between or among them could be represented as an error correction method (ECM).

Table 2.The Johansen cointegration test resulted is presented below

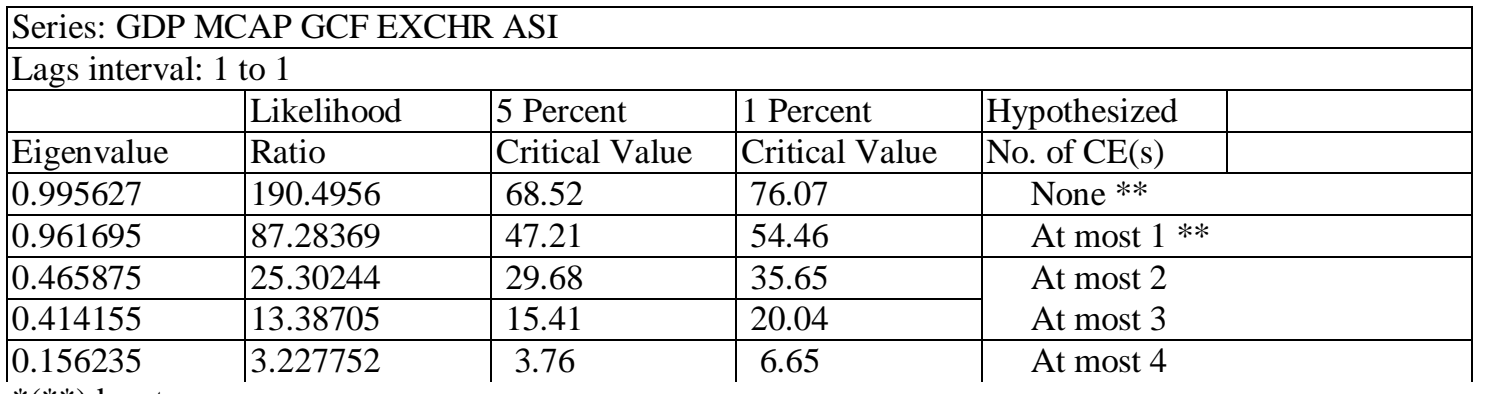

$*(* *)$ denote

Denotes

rejection of the

hypothesis at

$5 \%(1 \%)$

significance

level

L.R. test

indicates 2

cointegrating

equation(s) at

$5 \%$ significance

level

The result in table 2 (cointegration result) implemented with linear deterministic trend indicates the presence of two cointegrating equations at $5 \%$ and $1 \%$ level of significance. This means that long run 
equilibrium relationship exist among the variables in the model. We therefore reject the null hypothesis of no long run equilibrium relationship (cointegration) among the variables (GDP, ASI, MCAP, GCF, EXCHR) in the model.

The next step is to perform the over parameterised and parsimonious error correction method to account for short- run dynamic adjustments required for stable long run relationship among the variables in the model.

The over parameterized model is presented in table 3. The over parameterized model account for model misspecification problems as a step towards arriving at a preferred or parsimonious model. This is presented below

Table 3 Over-Parameterised Error Correction Results.

Dependent Variable: GDP

Method: Least Squares

Sample(adjusted): 1980-2011

Included observations: 32 after adjusting endpoints

\begin{tabular}{|c|c|c|c|c|}
\hline Variable & $\begin{array}{l}\text { Coefficien } \\
\mathrm{t}\end{array}$ & Std. Error & t-Statistic & Prob. \\
\hline $\operatorname{GDP}(-1)$ & 0.81196 & 0.144556 & 5.616754 & 0.0014 \\
\hline $\mathrm{C}$ & 627.614 & 265.9437 & 2.359945 & 0.0563 \\
\hline ASI & -0.04768 & 0.121378 & -0.392893 & 0.7080 \\
\hline $\mathrm{ASI}(-1)$ & -0.147616 & 0.092081 & -1.603104 & 0.1600 \\
\hline EXCHR & 17.04359 & 6.752627 & 2.523995 & 0.0450 \\
\hline $\operatorname{EXCHR}(-1)$ & -15.38536 & 9.280080 & -1.657891 & 0.1484 \\
\hline GCF & 2.656425 & 1.284758 & 2.067647 & 0.0842 \\
\hline $\mathrm{GCF}(-1)$ & 2.432040 & 1.622209 & 1.499215 & 0.1845 \\
\hline MCAP & -0.340765 & 0.374634 & -0.909593 & 0.3981 \\
\hline MCAP(-1) & 1.177959 & 0.490508 & 2.401508 & 0.0532 \\
\hline $\operatorname{ECM}(-1)$ & -0.279037 & 0.115985 & -2.405802 & 0.0463 \\
\hline R-squared & 0.999070 & \multicolumn{2}{|c|}{ Mean dependent var } & 8142.63 \\
\hline Adjusted R-squared & 0.997520 & \multicolumn{2}{|c|}{ S.D. dependent var } & 8444.54 \\
\hline S.E. of regression & 420.5029 & \multicolumn{2}{|c|}{ Akaike info criterion } & 15.1734 \\
\hline Sum squared resid & 1060936. & \multicolumn{2}{|c|}{ Schwarz criterion } & 15.7128 \\
\hline Log likelihood & -117.9743 & \multicolumn{2}{|c|}{ F-statistic } & 644.655 \\
\hline Durbin-Watson stat & 2.322120 & \multicolumn{2}{|c|}{ Prob(F-statistic) } & 0.00000 \\
\hline
\end{tabular}

In the over parameterized model as shown in table 3, the error correction term ECM(-1) is correctly specified. It is negative and statistically significant. This conforms to our earlier assertion that the variables in the model are cointegrated. The coefficient of the ECM is the speed of adjustment from short-run disequilibrium to long-run equilibrium. It also means that about 28 percent disturbances or shocks in the previous year adjust back to equilibrium in the long-run or current period.

The adjusted $\mathrm{R}^{2}$ in the over parameterized model is 0.997520 . This means that about 99 percent of the variations in the dependent variable (GDP) is explained jointly by all the regressors in the model. The explanatory power of the model is very high and is a good fit, leaving about 1 percent for the stochastic or unexplained variable. The F statistics of 644.655 with probability of 0.000000 is highly significant. This means that the independent variables in the model (ASI, EXCHR, GCF, MCAP) are jointly significant i.e the variables fit well in the model.

The AIC and Schwarz information criteria are within the acceptable limit and therefore shows correct specification of the model. The model passes both the diagnostic and the normality test. The Durbin Watson statistics ' $D$ ' of 2.322120 means the absence of serial or auto correlation.

GDP (-1) is positive and statistically significant. This means that GDP in the one lag period impacts positively and significantly on current period GDP. This satisfies Apriori expectations. EXCHR and GCF in the current period is positive but statistically significant but in the one lag period, the impact of EXCHR on GDP was negative and statistically insignificant. The impact of GCF in the one lag period is positive but insignificant, its coefficient is 2.432040.This satisfy apriori expectations. This means that a unit change in EXCHR and GCF in the current period brings about 17.04359 and 2.656425 change respectively in GDP. Also, MCAP is negative at current period and statistically insignificant but in the one lag period, its impact is positive and statistically significant. This satisfy apriori expectations. MCAP satisfy apriori expectation in the current period but negate apriori expectation in the lag period. 
The impact of ASI in both the current and one lag period was negative and statistically insignificant. This also negates apriori expectation which means that for this work, ASI does not impact GDP both in the short run and in the long run analysis.

The next step is to perform the parsimonious model which is a stepwise reduction of jointly insignificant variables in the over parameterized model until parsimony is obtained. This is presented in table 4

Table 4. Parsimonious Error correction Results

Dependent Variable: GDP

Method: Least Squares

Sample(adjusted): 1980-2011

Included observations: 32 after adjusting endpoints

\begin{tabular}{lllll}
\hline \hline Variable & Coefficient & Std. Error & t-Statistic & Prob. \\
\hline \hline GDP(-1) & 1.222951 & 0.054337 & 22.50662 & 0.0000 \\
C & 267.5577 & 290.8494 & 0.919918 & 0.3757 \\
ASI & 0.094533 & 0.014238 & -6.639427 & 0.0000 \\
MCAP(-1) & 0.846302 & 0.075808 & 11.16371 & 0.0000 \\
ECM(-1) & -0.493296 & 0.212583 & -2.3204866 & 0.0328 \\
\hline \hline R-squared & 0.995455 & Mean dependent var & 8142.63 \\
Adjusted R-squared & 0.993940 & S.D. dependent var & 8444.54 \\
S.E. of regression & 657.3590 & Akaike info criterion & 16.0547 \\
Sum squared resid & 5185450. & Schwarz criterion & 16.2993 \\
Log likelihood & -131.4613 & F-statistic & 657.089 \\
Durbin-Watson stat & 2.316045 & Prob(F-statistic) & 0.00000 \\
\hline \hline
\end{tabular}

In the parsimonious or preferred mode as shown in table 4, the ECM is correctly specified. It is negative and statistically significant. In the parsimonious model, the speed of adjustment which is the coefficient of ECM is high. It shows that about 49 percent of short-run disequilibrium adjusts back to equilibrium in the long-run. The statistically significant coefficient of the ECM means that the variables in the model are cointegrated and are therefore useful in policy formulation and implementation. The sign and magnitude of the ECM implies that the model passes the normality assumption of OLS. This means that the OLS estimation is consistent, unbiased and follow a normal distribution. We therefore reject the null hypothesis that the error term is not normally distributed at the respective level of significance. The value of adjusted $\mathrm{R}^{2}$ of 0.993940 means that the explanatory power of the model is very high. About 99 percent change in GDP is explained jointly by all the explanatory variables in the model leaving about one percent for the unexplained variable or stochastic term. The F statistics of 657.089 in the result is highly significant. This implies that the independent variables fit well into the model. It is a good fit. The model passes the goodness of fit test.

The AIC and Schwarz information criteria for model specification shows that the model GDP=F(ASI, EXCHR, MCAP, GCF) is correctly specified.

The Durbin Watson statistics of 2.316045 means the absence of auto or serial correlation.

GDP (-1) satisfy apriori expectation. It is positive and statistically significant. This implies that a unit change in GDP in the 1 lag period brings about 1.222951 changes in GDP in the current period.

The null hypothesis of no significant positive relationship between the performance of the Nigerian Stock Exchange and economic growth is rejected at $1 \%, 5 \%$ and $10 \%$ level of significance because MCAP in the one lag period was positive and significant.

\section{Rec0mmendations}

Based on the finding of this study, it is clear that the Nigerian Stock Exchange like other stock exchange in the world is the pivot on which our economy revolve. To enhance the level of economic growth, the activities of the Nigerian Stock Exchange need great improvement as recommended below:

1. From the parsimonious results, ASI was negative but highly significant which means that if the stock market can be more efficient, all share index will appreciate and this will cause an increase in GDP.

2. Also Market Capitalization (MCAP) which is positive and highly significant in the parsimonious tests shows that market capitalization is an essential part of the Stock Market variables that can promote economic growth of the country.

3. The stock exchange need to embark on measures which will help to stimulate the interest of the public in stock exchange operations and create more effective mobilization of capital and the extension of brokerage services to cover all nooks and cranny of the country. 
4. The relationship between the exchange and media houses should be strengthened. This is vital because the multiplier effect in informing the investing public will be high.

5. The Nigeria Stock Exchange should go international. Internationalization in this context means that the Nigerian Stock Exchange should admit foreign stock for quotation.

6. The outcome of privatization should be improved efficiently for the economy whereby more people would be encouraged to acquire shares.

The tremendous advances recorded in the past are no doubt indicative of future prospect which may translate into bigger challenges in the years ahead. For instance, the information explosion recorded had made interact trading in securities possible in some countries. While in Nigerian capital market has no doubt recorded some significant growth since its inception, a lot still remains to be done in the areas of creating public awareness.

Similarly, a lot is still required in the aspect of improving the operational efficiency, enhancing the depth and breadth of the market and building regular capacity. It is necessary and crucial for economic development of a country as the stock market helps in the socio-economic integration of all areas of the country. This is because, of the roles and opportunities which the stock market offers for the continuous trading in securities issued by the users.

\section{Conclusion}

The role of the Stock Market in Nigeria cannot be over-emphasized. The low levels of development of the Nigeria economy coupled with the political instability have also greatly affected the proper functioning of the stock exchange. On the economic level is the lower income per capita of Nigerians. This has reduced the propensity to save and invest by Households.

On the part of the government, there appears to be low level of incentives towards the development of capital market in the country. The need for involvement of private individuals in the economy has been realised with the government structural adjustment programme established in the past, privatization and commercialization of some firms which were formerly owned by government are now in the hands of individuals.

However, another drawback towards achieving this is the hyper-inflation currently raging through the country. A lot of household income is currently being spent on food as basic necessity while the income had remained nearly constant. The taste of Nigeria for foreign made goods continued to encourage capital flight. The little foreign exchange that would have been used for industrial development was directed to the purchase of finished goods.

Also lack of credibility and inconsistency in government macroeconomic policies negatively affects stock market operations. Since independence each successive government came with a change in policy with regards to investment and other economic problems.

A good number of the public including the educated ones, do not quite understand what the Nigerian stock exchange is all about in terms of its operations. Such lack of awareness on the part of the public could not be said to be good enough for healthy growth both of the capital market and the economy.

Furthermore, industrialists who would have utilized such abundant opportunity offered by the capital market are scared as a result of the stringent stock exchange listing requirements. Despite these short-comings of the Nigerian Stock Exchange, the future of the Nigerian Stock Exchange remains bright as more efforts should be directed towards ensuring better services in the near future.

\section{References}

[1]. Arestis,Demetriades \& Luintel (2001). Financial Development and Economic Growth: The role of Stock market. Journal of money, credit and banking. 33(1):16

[2]. Fama E.F (1976). Efficient Capital Market. Review of Theory and Empirical Work. Journal of Finance Chapter 25:383-417.

[3]. Harris, Richard D.F (1997). Stock market and development: A re-assessment. European Economic Review, Elsevier, Vol. 41(1):139146

[4]. Mohtadi \& Agarwal(2008). Does Stock market development raise Economic growth? Evidence from Nigeria. Review of finance and banking. Vol.1 issue 1: 26-36

[5]. Nourzad (2002) Financial development and productive efficiency: A panel study of developed and developing countries. Journal of Economics and finance Vol. 26 no. $2: 123-134$

[6]. Robert Barro (1990) Stock market and investment. NEER working paper series, working paper no. 2925. National Bureau of Economic Research 1050 Massachusetts Avenue Cambridge, MA 02138, April.

[7]. Rose Levine \& Sara Zervos (1996) Stock market development and long run growth. Policy Research working paper 1582. The World Bank policy Research department. Finance and private sector development division, March.

[8]. Rousseau, P.L.\& Wachtel P. (2000) Efficiency markets and growth: Cross country evidence on timing and outcomes $1980-1995$. Journal of Banking and finance. Elsevier Vol. 24(12):1933-1957.

[9]. Seyyed A.P. Oskooe (2012) Emerging Stock market Efficiency, nonlinearity and Episodic Dependence Evidence from Iran Stock market. Journal of Basic and applied scientific research 2(11):11370-11380

\section{Acknowledgement:}

We wish to acknowledge the moral support given by Profs: Gesiye Salo Angaye, Akpan H. Ekpo, Nyong M.O and Wilfred A. Ndongko. 